International Journal of Engineering \&Technology, $7(3.12)(2018) 98-107$
SPC
International Journal of Engineering \& Technology
Website: www.sciencepubco.com/index.php/IJET
Research paper

\title{
Evaluation of Investor Awareness on Techniques used in Stock Trading before their Investment
}

\author{
B.Vidhya ${ }^{1}$, S.Magesh ${ }^{2}$ \\ ${ }^{1}$ Research Scholar, ${ }^{2}$ Professor, ${ }^{1,2}$ Department of Computer Science and Engineering, \\ Saveetha School of Engineering, Saveetha Institute of Medical And Technical Sciences. \\ *Corresponding Author Email: ${ }^{1}$ bvidhyaa@saveetha.com, ${ }^{2}$ mageshs.sse@ saveetha.com
}

\begin{abstract}
Indian stock exchange is one of the world's largest stock market. It holds 16,993,616 active demat account investors as on February 2018, where the investor trade the equities. An equity holding will make the investor to own a percentage of the company's capital. The value of the investment raise as the company develops, initially it starts with Initial Public Offering (IPO) which will be allotted by the companies. This will be listed in stock exchange for secondary market. The investor decides whether to hold the stock for a longer or shorter period depending on the percentage of returns. Most of the research studies had concluded that Indian stock market is highly volatile, sensitive, reactive to news and unanticipated shocks. This instantly has an impact on the market trend activities, but it resilient and recovers soon. The investor aims for high returns on the investment, and experience a high risk. Since the direction of market is unpredictable and lack of knowledge for the success factors, leads to fear on investing in stock market. Practically the risk and returns are directly proportional. However the risk-return perceptions of the investor may vary.

The aim of this study is to analyse acquaintance level of the investor in stocks trading and the technical knowledge to overcome the risk factors while trading in live market before investing.
\end{abstract}

Keywords: Stock market, Stock Trading, Investor, Investment, analysis, techniques

\section{Introduction}

Capital Market are of

1) Primary market - purchase of shares via IPO (Initial Public Offering) allotted by companies who issue public offers of shares. ( www.nse.com)

2) Secondary market - Stock trading done via exchanges who is ready to purchase from primary shareholders after listing in exchanges, and resale in secondary market.

Stock trading means a person or a company involved in trade of equity securities via stock exchange by holding an Demat Account. Stock trading can be performed by the investor with the help of an stock broker / sub broker, agent registered under SEBI, who is the stock market regulator (12). Agents make a commission for each trade of stock / equity from the trader, who trade on behalf of a investor.

A stock (also called as share / equity) market is the assortment of investors for shares (buyers and sellers). A broker and trader can

buy and sell shares of stock, bonds, and other securities at an agreed price listed on a public stock exchange.

A investor tactics about his investment and returns since there are wide range of investment mode exist like Mutual Fund (SIP), Commodities, Equity Shares, Options, Futures, IPO, Foreign Exchange, Gold ETF, Bonds, Post Office Saving Schemes, Company Fixed Deposits, Insurance Plans, Retirement Plans, PPF, etc. Retail investment and institutional investment are two different manner available for traders, the trader need to do technical or fundamental analysis to have maximum returns with minimum risk for investment.
Exchanges act as the hub centre for each transaction, meaning that they collect and deliver the shares, and guarantee payment to the seller of a security. This eliminates the risk to an individual trader that the counterparty could default on the transaction. There are many exchanges existing, out of which BSE (Bombay Stock Exchange) and NSE (National Stock Exchange) account's most of the trading shares in India.

Types of trading in Stock market: 


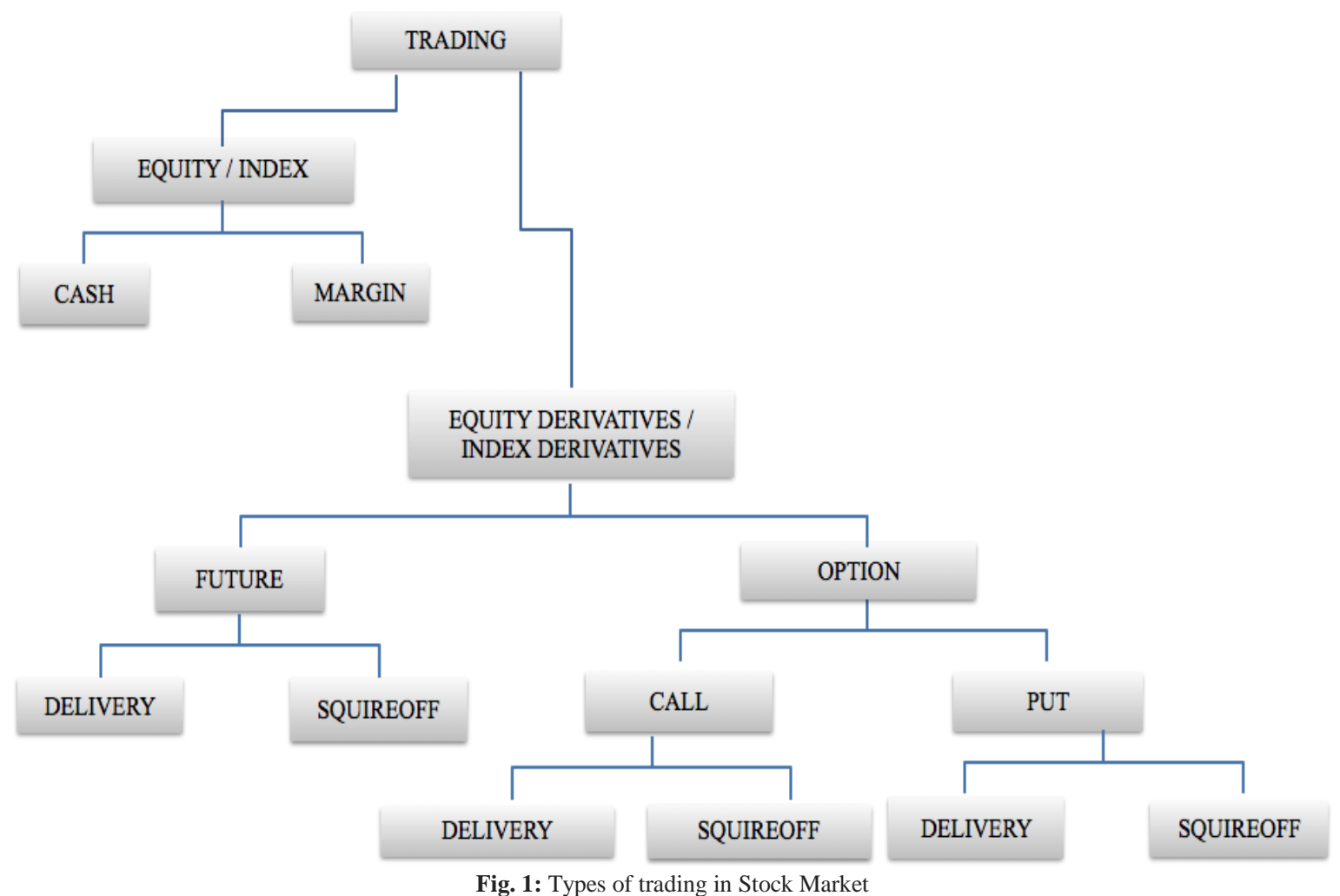

Equity trading (no expiry), Owning the shares by purchase and finding profit within a day / week / month or years according to the percentage of returns planned by the investor.

Derivatives (last Thursday of the month has expiry), Derivative trading is a place where the trader can hold or trade the shares by giving a margin amount until a particular period. The holdings of lot will expire on last Thursday of that particular month. It is traders choice to choose the appropriate month of the lot for trading, capacity of investment to hold. The holding will get square off in case the trader not closing the holding on expiry day. The trading will be in lots and will differ in count for each company according to the weightage of the stocks. The value of the margin will be $10 \%$ value of the total shares and can hold it for its respective month expiry.

Monthly Trade has Futures Delivery - The trader purchase the lot and sell after enjoying the profit according to the expectation. Futures Square Off - In case the trader fails to close the holding, the lot gets automatically wind up according to the live stock price before closing time at 3:00PM.

The feature of the OPTION is a choice to predict a value to be of the stock in a week or month, An investor choose the stock by analysing the market trend as it increase or decrease in price of particular stock. If the prediction happens the investor gain if not vice versa.

Two manners are available for the traders to trade, CALL OPTION and PUT OPTION. Call option is a principle of buying the stock and selling the stock for specific price as per the market flow. Put options is a principle of making the to sell a stock at a specific price and buy back the stock in lesser stock price, this trading is most familiar in bear market.

Weekly option: Bank Nifty index - only has this feature for this type (every Thursday of the week it gets expire of that particular holding )

Commodity market feature expedite to trade commodities like silver, gold, crude oil, live cattle, rice, wheat, soybean, coffee, cotton, sugar etc., which falls under four categories of metal, energy, Livestock and meat, Agriculture products.

Trading can be done as a Spot or a Derivatives market. In Spot market, commodities are bought and sold for immediate delivery, whereas in Derivatives market, various financial instruments based on commodities are traded.
Mutual Funds - A sophisticated managed device to trade a conclave of money from many investors to invest in stocks, bonds and other securities is mutual fund. An investor procur mutual fund 'units', by holding share in a particular scheme. Fund's current net asset value (NAV) act as the value of the unit to purchase for the investor. NAVs keep fluctuating, according to the fund's holdings of the particular mutual fund instrument So, each investor decides to invest according to the proportionate in the gain or loss of the fund.

Investors in capital market have many types of instruments to invest. The trader / investor definitely has to analyse the methods, trends, and techniques available in each instruments before investing / trading in that particular platform. Due to lack of this awareness in investors it happens to face high risk even for a small returns.

Most of the research studies had concluded that Indian stock market is highly volatile, sensitive, reactive to news and unanticipated shocks. The investor aims for high returns on the investment, and experience a high risk to achieve. The direction of market is unpredictable and lack of knowledge for the success factors leads to fear for the investor on investing in stock market. The objective of the study is to explore the awareness of the investors about trading (technics) technologies, before their investment in stock market via survey.

\section{Review of Literature}

Wazal, Sudesh Kumar Sharma (2017) in their study measure the number of retail investors in the Indian equity market and how it compares with rest of the world. Population of retail investors in Indian equity market is dismally low when compared with other leading economies. It was justified the estimate population of retail investors at 4.45 percent of total Indian population. Over the time period, the numbers have increased since the investor confidence is being maintained investment in the equity market. Another noteworthy interesting fact is that more than $50 \%$ of the retail investment is from the western region of the country. Retail investors in India is disproportionately distribute with western region like from Mumbai and Pune Cities dominating with nearly half of the investor population. (1) 
M.Malathy, Saranya.J (2017) - Researcher conducted a survey to study the factors that influence Investors perception as well as to analyze the investor behavior and influence an investment decision. It was analyzed that the main factors influencing investments are the return on investment and the short-term profitability. Every investor should be very cautious in market trend or risk while investing since the respondents rated ROI very high. Return on investment (ROI) is a very important factor that influences the investment decision. Return is the ultimate aim for an investor. Hence, majority of respondents rated ROI very high. The main factors influencing investments are the return on investment and for the short-term profitability. (2)

Radhika M (2017) - In today's competitive environment, different kinds of investment avenues are available to the investor, but they should be intelligent enough to select the scheme in which they are going to invest. Investing in various types of assets is an interesting activity that attracts people from all walks of the life irrespective of their occupation, economic status, education and family background. An investor tries to balance the benefits and shortcomings of different investment modes before investing in them. The main focus of the research paper is to identify the investors' perceptions towards Mutual Funds and equity market with a sample of 100 investors in Hyderabad and Secunderabad. From the above study it has been noticed that Mutual funds are the better option for the investors compare to that of Equity. Investors have the perception that risk in equity is higher than mutual funds (3)

Raju N.S.V.N, Anita Patra (2016) - To analyse investor's Attitude towards Investment in Equity Stocks, research has been done in the selected areas of Visakhapatnam District (A.P.) a structured questionnaire was designed to collect primary data from 200 respondents by using convenience sampling method. By adopting five point likert scale and analysation has been executed using percentage method, Chi-Square test, weighted average ranking method. Indian stock market is considered to be highly volatile, sensitive and reactive to unanticipated shocks or news, it takes no time to impact the market activities. But it is resilient and recovers soon after shocks. The average value of the top highly influential factors, according to the investors, were what the company does, followed by company profitable, followed by history and outlook of the company's earnings, followed by business model of the company. (4)

Venkatesha. R and Hiriyappa (2017) - The researcher analyzes the perception of the investors towards NSE and BSE derivative market, the research was done by collecting datas from 150 respondents with a help of structured questionnaire. The results shows still awareness has to be given to investors even if there is a development among the investors in last five years, SEBi or any government body has to take responsibility for bringing the awareness and to train the technologies to overcome the risk factors associated with derivative trading. (5)

Arup Kumar Sarkar, Tarak Nath Sahu (2017) - The researcher has made a study to enquire the effect of Awareness of individual investor and Perceived Risk Attitude on the Investment Behaviour in Stock Market. The primary data has been analysed using tools and techniques, and probit regression by SPSS and Stata Softwares were implemented in datas collected from 500 randomly selected individual investors using a structured questionnaire from different districts of West Bengal. The researcher concludes that investors have only moderate level of awareness and there needs an improvement in the awareness in stock market activities for individual investors in market. (6)

Banumathy, R Azhagaiah (2016) The analysis is to study the awareness of investors on stock market investment. The data were collected from stock market investors via structured questionnaire. The Mann-Whitney U test and Kruskal-Wallis H Test were used for analysis. The study shows that awareness level differs between as gender, age and the awareness on investment also differs as their age, educational background, occupation. Thus the study says the investment and decision is been influenced by demographic variables like gender, age, marital status, education and income.

Mamtha and K. Sakthi Srinivasan ( 2017) in their study on Retail Investors Participation, perception, attitude and behaviour on Indian derivative Market. By framing a structured questionnaire a survey has been conducted from 250 respondents from vellore district. The result reveals the investor is aware of the risk in derivative trading and the returns are proportionate to the risk they take on investment. And the researcher says it is difficult to understand the investors since there are various factors like the attitude of expectation of percentage in gain level changes and so the governing bodies need to take steps to regulate the market and upskill the investors regularly in order to attain a efficient investors for the market. (8)

Kajal Gandhi (2016) in his study on retail investors attitude towards investment and perception on different aspects on stock market. There is a minimum percentage of investors are participating in the market even though it has a giant growth, investors plan for fixed, recurring deposits, bond etc. The market is dominated by Foreign and domestic Institutional investors. The survey was carried out in different cities to asses the retail investor participation. The result shows the retail investors in capital market is low when compared to their investment in savings, they feel complexity in investing in stock market A crusted action is required to sort out the issues like rate fluctuations, tainted accounting practices, overpricing and imprecise grading of IPOs. A firm regulation authority must take action against such unprofessionalism happening in Indian stock market for investors protection. (9)

Sangeeta Arora Kanika Marwaha (2014) This study was to analyse the investor's awareness on market investment and literacy level in financial sector. The survey was conducted among 100 responders in the area of Punjab, the result datas were analysed in the faces of frequencies, percentage and weighted average scores. The results reflects that individual investors in Punjab region has strong capacity on their trading features like benefits of diversification, Shares closing price, Current Market indices, Inflation, return etc. and least level of knowledge on Stock split, Interest rates on debentures / bonds and Bonds. The researcher has analyzed that investors need are in need of efficient advise on their investment decisions. (10)

Jaya and Malarvizhi (2017), verified the method of investment for stock investors and their risk assessment criteria. The motive for investing as well as the profile of the investors were also analysed based on age distribution, profession, educational qualification, investment percentage of income, aim and reason for stock market investment and the risk related to the investors' point of view (11) Rashmi Mate and Patil Vidyapeeth (2017) measured the financial literacy of investors as well as potential investors in the city of Pune. They surmised a correlation between financial literacy and investment participation. Their outcomes suggest that the financial literacy level is very low due to inexperience. They also observed that $28 \%$ of their participants were in the $30-35$ age range which indicate that lower age groups are interested in investing in stock markets. They inferred that even though the financial literacy is low, the younger age groups tend to participate more in investing (13)

Neha S Shukla (2016) analysed the inclination of professionals with fixed salaries towards the investment sector. A survey was conducted in North Gujarat region among 100 participants. It was observed that age and income are contributory factors for investment whereas educational qualification and gender have no effect on interest toward investment. Most of the investors choose post office saving schemes, fixed deposits in bank, investing in gold, silver and/or investing in housing or land, which shows that their objective is short term financial security with low risks for the future whereas only five percent of people prefer investment in stock market. (14)

Gopi and Paulraj (2017), analyzed the awareness of public investors on investment options and choices in share market using 
a survey in areas of Tambaram in Chennai with 138 participants. It was concluded that the investment is based on individual's opinion on the returns and risk. It was observed that most of the participants were more inclined to invest based on favorable wordof-mouth information. The authors recommend the use of campaigns to improve awareness on investing as well as inclusion of basic investment methods at the school level to inculcate interest and awareness among younger age groups. (15)

Rambabu et.al (2017), categorised the research work into two sections such as Put-Call options and Spot-futures. There is an arbitrage profit option which may be utilized using spot as well as future markets. The investor should have the stock in his position to buy futures and short the stock. Nowadays, in the modern world, trade using spot and future arbitrage is carried out by the utilization of supercomputers in which the return rates tend to be higher. (16)

\section{Proposed Architecture of the Study}

A structured review will first be performed to determine the most efficient method to elicit information from the participants. A Structured questionnaire will be prepared based on the HKEx Investor Survey (2015) which assessed the participation of overseas trading. This survey has been used frequently to determine the participation of retail investors' in derivatives market and securities in overseas products trading. The survey has been conducted among 2271 individuals, 1006 number of investors in stock market and 45 numbers of investors in derivatives market, using survey interviews (17).

The SEBI investor survey (2015) was also analysed as a reference for the proposed questionnaire. The SEBI survey not only quantifies the approach or conduct of investor and also examines the non-investors in security market. The survey was mainly carried out to determine the investment approach of households and also to evaluate the interest in securities market by the households and to derive the reason for non-participation in the securities and equity based market. The survey concludes only a limited proportion of the population in India has invested in stock market even though the country comprises a robust stock market (18).

\section{Tools for the Analysis of the Data}

Microsoft Excel is a user friendly software for statistical analysis. Excel has the basic features of spreadsheets and various statistical functions. The data can be visually depicted as line graphs, histograms, charts, and three-dimensional diagrams. An Excel application can automatically poll external databases and measuring instruments using an update schedule, analyze the results, make a Word report or PowerPoint slide show, and e-mail these presentations on a regular basis to a list of participants.

SPSS Statistics is owned by IBM and is used for statistical analysis of data from any source, like scientific research, a customer database, Google Analytics, etc. SPSS can execute any file format that are commonly used for structured data such as spreadsheets, plain text files and relational (SQL) databases. SPSS is used for survey and deployment, data mining and text analytics MATLAB is a generic analysis framework, which requires programming skills. This makes it difficult for the average researcher to use unless he/she is specifically trained in the software. MATLAB contains an impressive collection of analytic libraries. It can clean up and pre-process the data, generate results and graphics which is fully customizable.

Weka is another tool for data analysis which has predictive modeling and a convenient graphical user interface for easy access to these functions. Weka supports several standard data mining tasks, more specifically, data preprocessing, clustering, classification, regression, visualization, and feature selection. It is also well-suited for developing new machine learning schemes.

$\mathrm{R}$ programming language is of interest to statisticians, data scientists, and data visualisation experts since it is free, and has a large and growing set of libraries for analytics, data manipulation, and charting. The programming language Python is also being adopted as an alternative to $\mathrm{R}$.

For this study, Excel statistics has been employed to evaluate the results from the questionnaire.

The questionnaire used for the survey

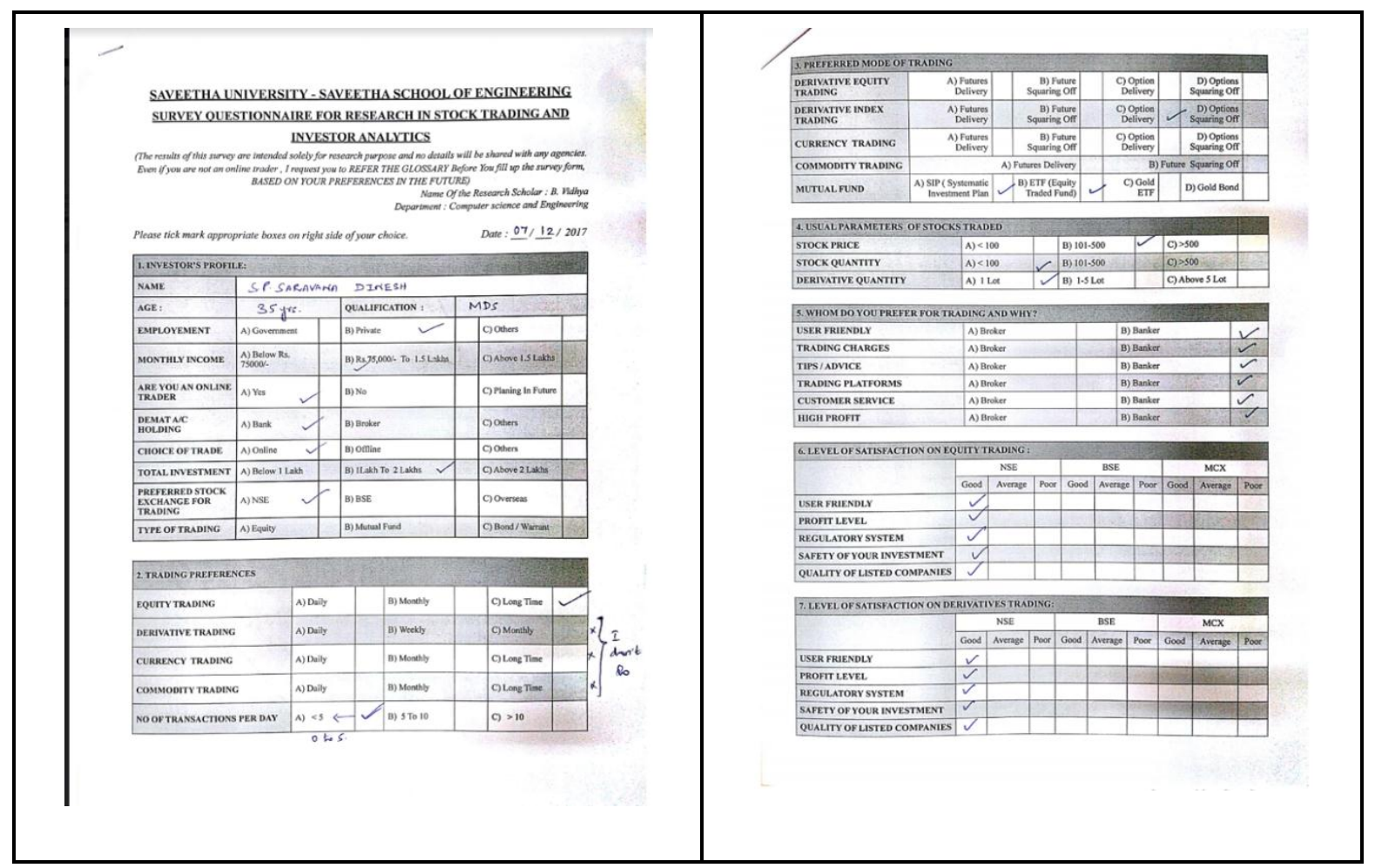




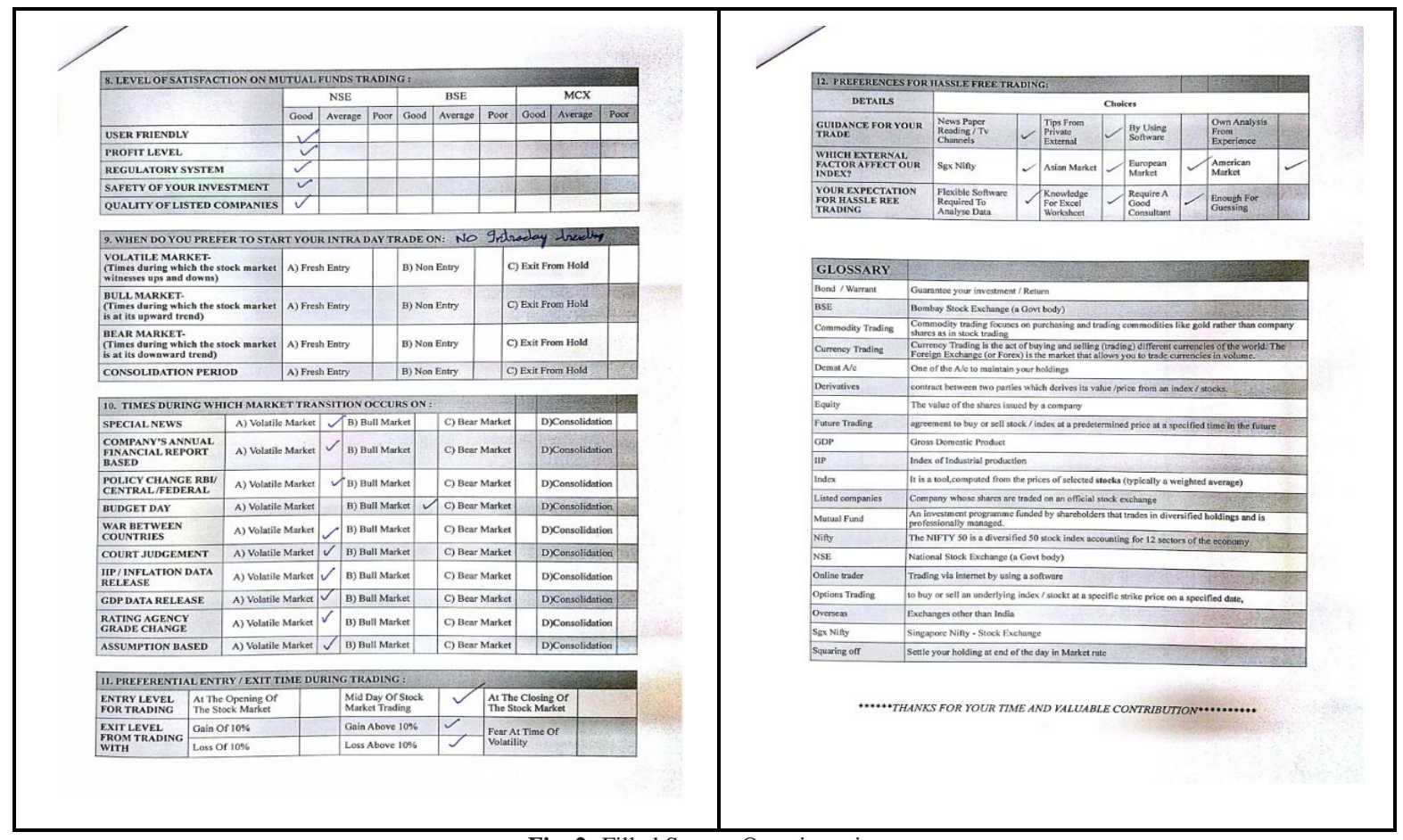

Fig. 2: Filled Survey Questionnaire

\section{Database and Research Methodology}

The present study is mainly based on primary data collected from 500 respondents via survey Questionnaire among the professionals of Doctors, Engineers, Business People, Administrators, Students, Govt employee of common people. The investors were interviewed with a well structured questionnaire which was structured with help of a review of articles based on surveys on stock market. The 327 responses were identified as investor and rest are non investors in stock market trading, the investors were sought for identifying and analysing the awareness of the investor's knowledge on share trading before the investment, and their preference in Demat account holding, to analyse which type of evaluation the investor do for having a hassle free trading, preference in mode of trading, preference in trading practice. most preferences, execution among a govt employee, private employee, and a business person.

\section{Graphical Representation of Analysis}

\section{A) Preference in Account Holding for Trading}

Table 1: Preference in Account Holding for Trading (\%)

\begin{tabular}{|c|c|c|c|c|c|}
\hline \multicolumn{7}{|c|}{ PREFERENCE IN ACCOUNT HOLDING FOR TRADING (values in \% of total Responds ) } \\
\hline & GOVT & PRIVATE & BUSINESS & PERCENTAGE AMONG BANKER AND BROKER & TOTAL PERCENTAGE \\
\hline BANKER & 11.31 & 8.87 & 9.79 & 29.97 & 27.7 \\
\hline BROKER & 14.98 & 29.05 & 25.99 & 70.03 & 64.6 \\
\hline BOTH & 2.75 & 4.28 & 1.31 & & 7.7 \\
\hline
\end{tabular}

PREFERANCE IN ACCOUNT HOLDING FOR TRADING

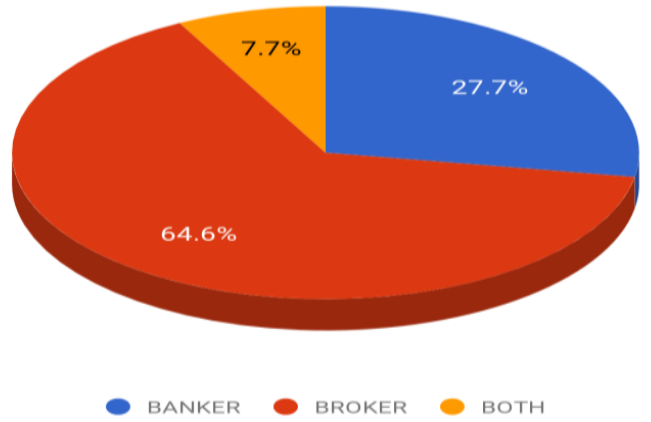

Fig. 3: Preference in Account Holding for Trading (values in \% of total Responds)

\section{Inference}

Table 1 and the pie diagram manifest the percentage of demat account holders' preferred channel for trading. It has been evaluated that $64.6 \%$ of investors trade via brokers and $27.7 \%$ of investors trade via bank demat accounts. Furthermore, $7.7 \%$ of investors avail both brokers and banks' demat account on trading. 

Table 2: Preference In Account Holding for Trading (values are number of responds)

\begin{tabular}{|c|c|c|c|}
\hline \multicolumn{2}{|c|}{ PREFERENCE IN ACCOUNT HOLDING FOR TRADING (values are number of responds) } \\
\hline & GOVT & PRIVATE & 29 \\
\hline BANKER & 37 & 95 & 32 \\
\hline BROKER & 49 & 14 & 85 \\
\hline BOTH & 9 & 124 & 46 \\
\hline TOTAL RESPOND ( EXCLUSIVE OF BOTH ) & 86 & 117 \\
\hline
\end{tabular}

\section{PREFERENCE IN ACCOUNT HOLDING FOR TRADING}

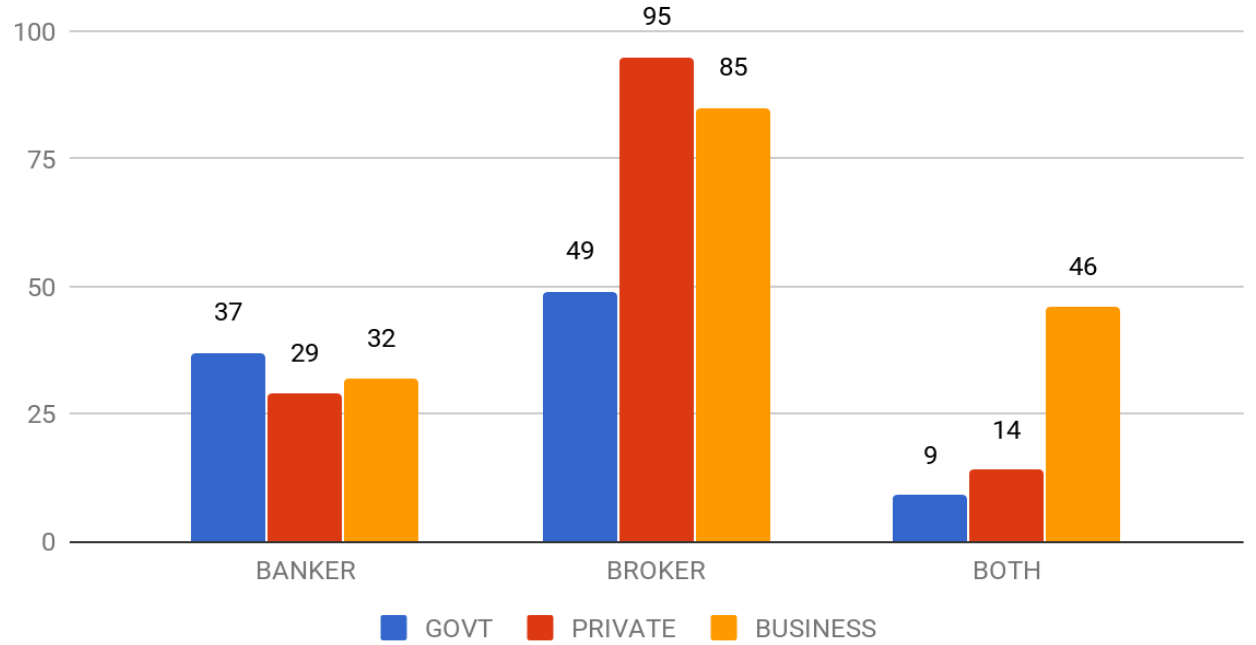

Fig. 4: Preference in Account Holding for Trading (values are number of responds)

\section{Inference}

Table 2 and its graph representation on figure no 4, shows the number of responds who had responded for the preference in demat account holding for trading. There observe the government employee out of 86 investors 37 trade via bank, 49 trade via broker, 9 of them trade using both account holding. Out of 124 private employe 29 depends on brokers for trading, 95 investors depend on brokers to trade and 14 investors are active on both bank and broker for trading. Out of 117 investors of businessman 32 investors accounts holds with brokers and 85 investors holds account with bank for trading, It has revealed that 46 businessman holds both the demat accounts for trading.

\section{B) Preference to Have a Hassle Free Trading}

Table 3: Preference to Have a Hassle Free Trading (values in \% of total Responds)

\begin{tabular}{|c|c|c|c|c|}
\hline \multicolumn{7}{|c|}{ PREFERENCE TO HAVE A HASSLE FREE TRADING (values in \% of total Responds ) } \\
\hline & GOVT & PRIVATE & BUSINESS & PERCENTAGE \\
\hline SOFTWARE SKILL TO ANALYSE DATA & 3.06 & 14.98 & 9.48 & 27.52 \\
\hline ESSENTIAL KNOWLEDGE ON TRADING INSTRUMENTS & 7.34 & 11.93 & 9.79 & 29.05 \\
\hline DEPEND ON GOOD CONSULTANT / BROKER / BANKER & 12.54 & 4.59 & 3.67 & 20.80 \\
\hline ANALYSE THEMSELVES TO GAIN AWARENESS & 3.36 & 6.42 & 12.84 & 22.63 \\
\hline
\end{tabular}

PREFERENCE TO HAVE A HASSLE FREE TRADING

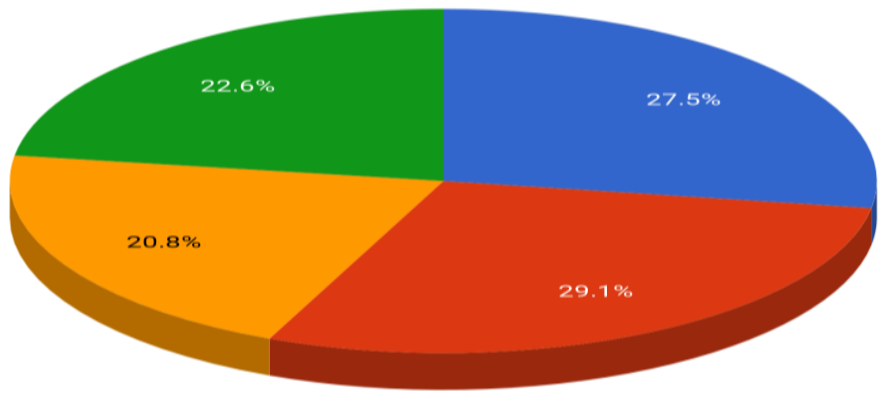





\section{Inference}

Table 3 and figure no.5, shows the investors choice of tool to get knowledge and to analyse their trade of investment, here it shows the the $27.5 \%$ of the investors depend on software to analyse, 29.1
$\%$ of investors say investor should have enough knowledge on instruments available in trading, $20.8 \%$ investors depends on good consultant / broker / bank advisor, $22.6 \%$ of the investors analyse themselves to have a hassle free trading.

Table 4: Preference To Have A Hassle Free Trading (values are number of responds)

\begin{tabular}{|c|c|c|c|}
\hline \multicolumn{2}{|c|}{ PREFERENCE TO HAVE A HASSLE FREE TRADING (values are number of responds) } \\
\hline & GOVT & PRIVATE & BUSINESS \\
\hline SOFTWARE SKILL TO ANALYSE DATA & 10 & 49 & 31 \\
\hline ESSENTIAL KNOWLEDGE ON TRADING INSTRUMENTS & 24 & 39 & 32 \\
\hline DEPEND ON GOOD CONSULTANT / BROKER / BANKER & 41 & 15 & 12 \\
\hline ANALYSE THEMSELVES TO GAIN AWARENESS & 11 & 21 & 42 \\
\hline
\end{tabular}

PREFERENCE TO HAVE A HASSLE FREE TRADING

49

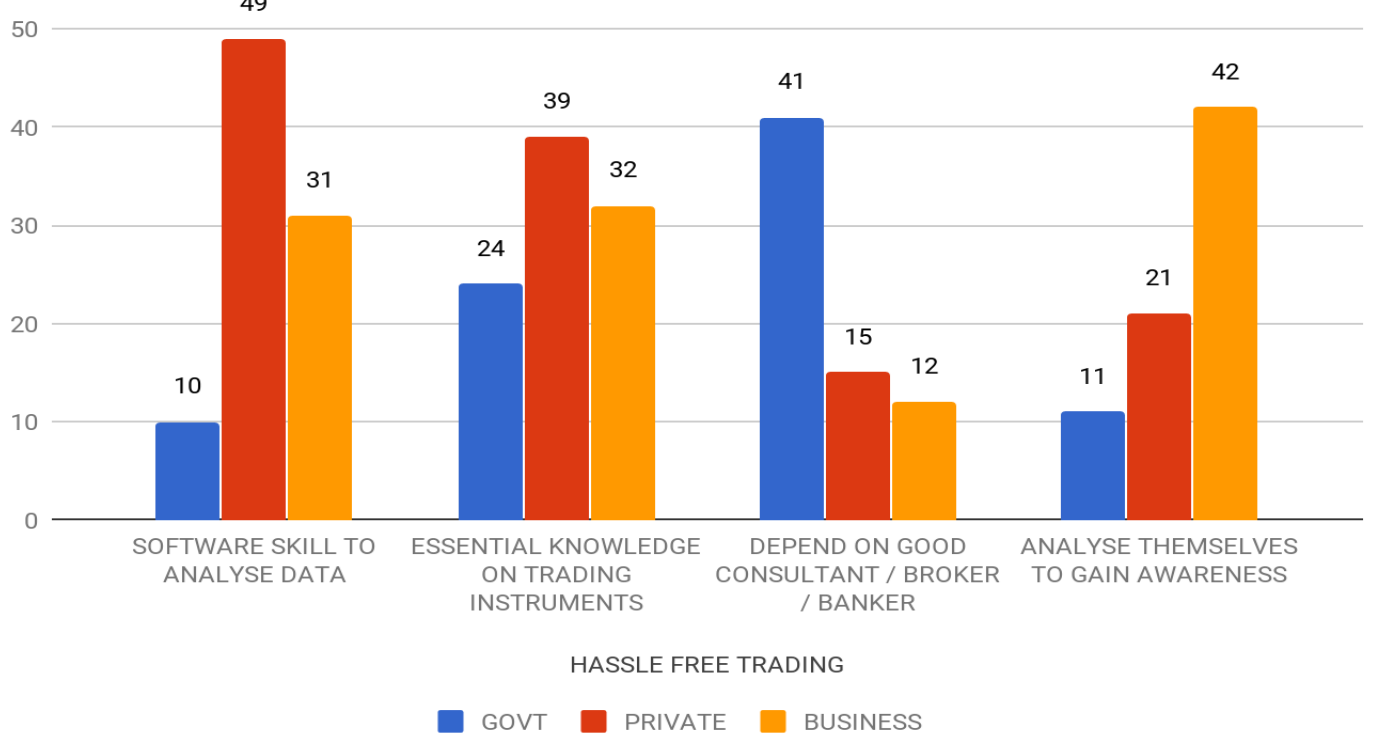

Fig. 6: Preference to Have a Hassle Free Trading (values are number of responds)

\section{Inference}

The Table 4 and bar diagram above, gives the numbers of responds opted their preference to procure information for hassle free trading. Here the out of three category of investors government employee 10, 11, 24 responses on software skill, self analysis and knowledge on instruments for trading respectively, whereas 41 investors depend more on consultant out of 86 traders to have a hassle free trading The 49 private employee is familiar with software analysis, and 39 says the investor need essential knowledge on trading instruments, whereas 15 dependents on consultant which is low when compared to 21 self analysis out of 124 total investors respond. From business category 31, 32, 12 investors responded that need for software skill, knowledge on trading instruments, depend on consultant / broker / banker respectively whereas 42 responded that they analyze themselves.

\section{C) Preference on Different Mode of Trades}

Table 5: Preference on Different Mode of Trades (values in \% of total Responds)

\begin{tabular}{|l|c|c|c|c|}
\hline \multicolumn{5}{|c|}{ PREFERENCE ON DIFFERENT MODE OF TRADES (values in \% of total Responds ) } \\
\hline & GOVT & PRIVATE & BUSINESS & PERCENTAGE \\
\hline ONLY EQUITY & 13.76 & 8.56 & 5.81 & 28.13 \\
\hline EQUITY \& DERIVATIVES & 10.09 & 23.24 & 13.15 & 46.48 \\
\hline EQUITY, DERIVATIVES \& CURRENCY & 2.45 & 4.28 & 9.79 & 16.51 \\
\hline EQUITY, DERIVATIVES, CURRENCY AND COMMODITY & 0.00 & 1.83 & 7.03 & 8.87 \\
\hline
\end{tabular}




\section{PREFERENCE ON DIFFERENT MODE OF TRADES}

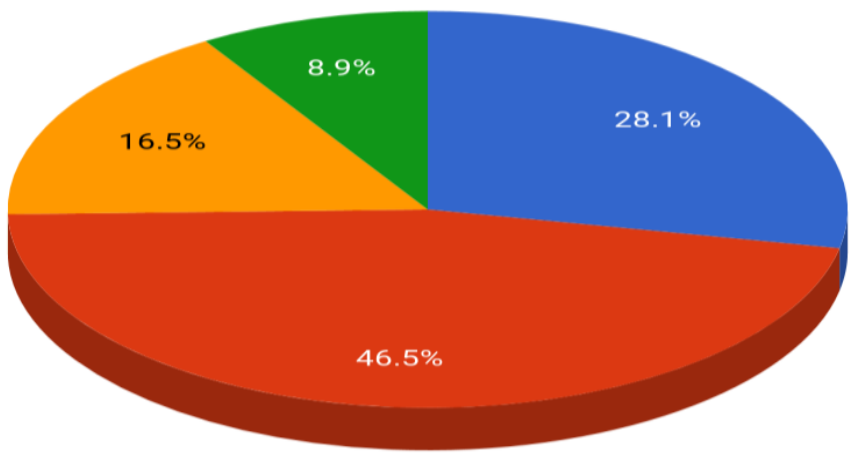

ONLYEQUITY EQUITY \& DERIVATIVES EQUITY, DERIVATIVES \& CURRENCY

- EQUITY, DERIVATIVES, CURRENCY AND COMMODITY

Fig. 7: Preference on Different Mode of Trades (values in \% of total Responds)

\section{Inference}

Table No. 5 and the pie diagram reveals the percentage of investors involved in different means of trading available in stock market trading. the percentage on equity and derivative trading shows maximum of $46.5 \%$, only equity trading shows $28.1 \%$, equity, derivative, currency trading shows $16.5 \%$ and all 4 types of trading which includes commodity is done only by $8.9 \%$ of the 327 total responds.

Table 6: Preference on Different Mode of Trades (values are number of responds)

\begin{tabular}{|l|c|c|c|}
\hline \multicolumn{2}{|c|}{ PREFERENCE ON DIFFERENT MODE OF TRADES (values are number of responds) } \\
\hline ONLY EQUITY & GOVT & PRIVATE & BUSINESS \\
\hline EQUITY \& DERIVATIVES & 45 & 28 & 19 \\
\hline EQUITY, DERIVATIVES \& CURRENCY & 33 & 76 & 14 \\
\hline EQUITY, DERIVATIVES, CURRENCY AND COMMODITY & 8 & 32 \\
\hline
\end{tabular}

\section{PREFERENCE ON DIFFERENT MODE OF TRADES}

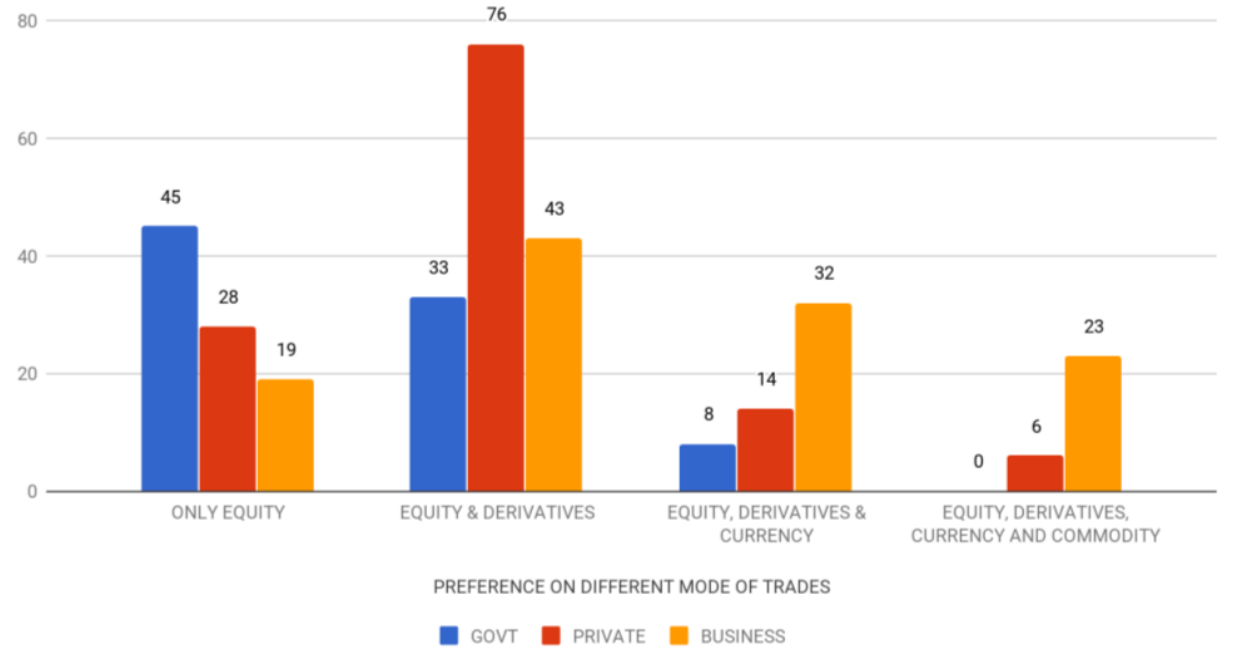

Fig. 8: Preference on Different Mode of Trades (values are number of responds)

\section{Inference}

Table 6 and its graphical representation show the number of responds opted for the mean of trading they execute for investment. In government employee category 48 investors execute only equity trading, 33 investors do both equity and derivative trading, 8 investors invest in equity, derivative and currency and none of them prefer for commodity out of 86 responds. In private employee category 28 investors interested to invest in equities, 78 investors opted they do both equities and derivatives, 14 investors responded for equity, derivative, currency trading, 5 has says that they trade all the said above along with commodities out of 124 responses. In businessman category 19 investors say they do only equity, 42 investors do equity and derivative, whereas 32 that is majority of the business man do equity, derivative and currency trading and 23 investors convey that they do all equity, derivative, currency and commodity trading which has the more reaction when compare to other category. 
Table 7: Trading Practice Preference (values in $\%$ of total Responds)

\begin{tabular}{|l|c|c|c|c|}
\hline \multicolumn{5}{|c|}{ TRADING PRACTICE PREFERENCE (values in \% of total Responds ) } \\
\hline & GOVT & PRIVATE & BUSINESS & PERCENTAGE \\
\hline PERSONAL TRADING & 2.75 & 17.74 & 33.03 & 53.52 \\
\hline DEPENDENT TRADING & 23.55 & 20.18 & 2.75 & 46.48 \\
\hline
\end{tabular}

TRADING PRACTICE PREFERENCE

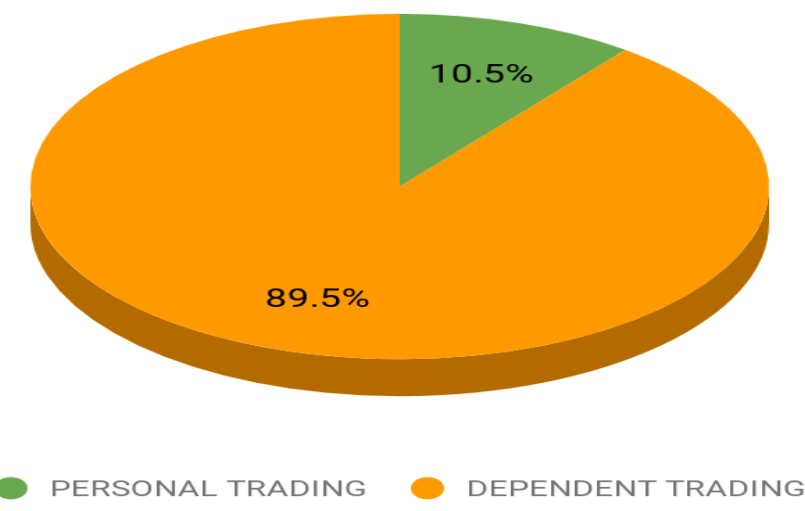

Fig. 9: Trading Practice Preference (values in \% of total Responds )

\section{Inference}

Table 7 and the pie chart shows the preference for trading, 10.5\% responded for personal trading or individual trading, whereas 89.5 $\%$ responses opted for dependent tradings.

Table 8: Trading Practice Preference (values are number of responds)

\begin{tabular}{|c|c|c|c|}
\hline \multicolumn{4}{|c|}{ TRADING PRACTICE PREFERENCE (values are number of responds) } \\
\hline & GOVT & PRIVATE & BUSINESS \\
\hline PERSONAL TRADING & 9 & 58 & 108 \\
\hline DEPENDENT TRADING & 77 & 66 & 9 \\
\hline
\end{tabular}

\section{TRADING PRACTICE PREFERENCE}

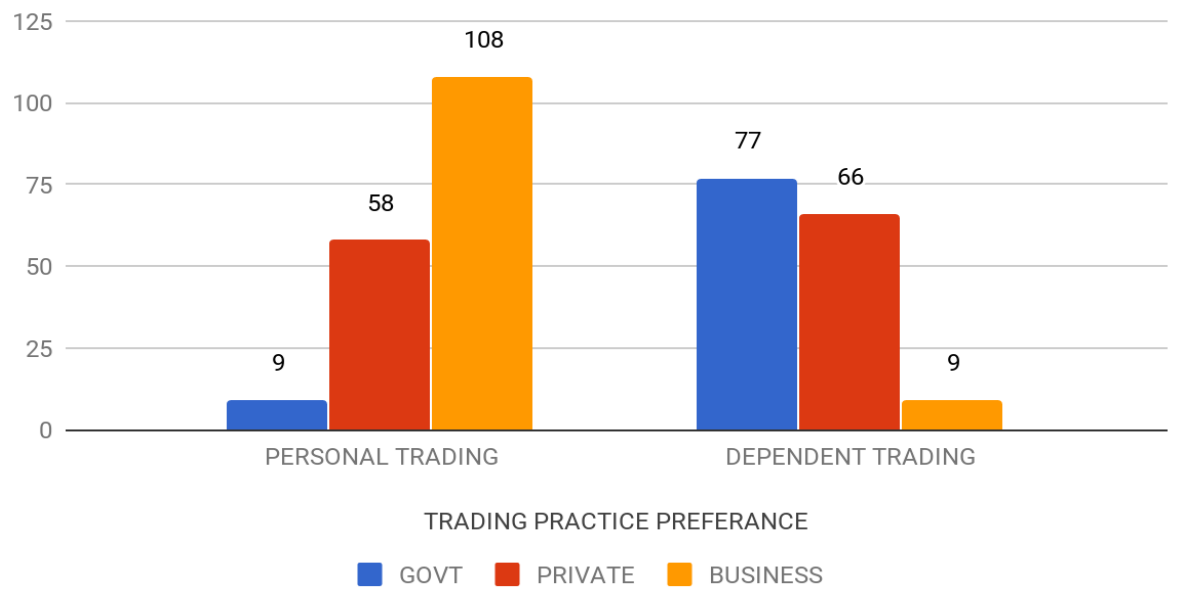

Fig. 10: Trading Practice Preference (values are number of responds)

\section{Inference}

Table no. 8 and its chart shows individual character for choosing the the trading practice,. the personal trading has 9, 58, 108 responses from government employee, private employee, business man respectively, it is noted the $10 \%$ of total responses is been opted by business man. the dependent practice is high for a government, private employee and number of businessman response is very low as $77,86,9$ responses respectively.

\section{Findings}

Nature of inferences from the data obtained

1) Investors differ in expectancy level in percentage of returns, since people involved in trading are of many categories

2) Lack of knowledge in techniques, to utilize while trading,

3) Restrict from trading since they could not analyse / predict the direction of market

4) Analysis of market is not done by their own, mostly investors are dependent on social media and believe in word of mouth. 
5) Belief in long time investment is comparatively lower than mutual funds

6) Lack of Awareness in Future, options, and commodity trading

7) Lack of Awareness in intraday trading

8) Lack of knowledge in features available in trading.

9) Study of factors influencing investor decision

10) To make appropriate suggestions to small equity investors to make their investment decisions effective

\section{Conclusion and Future Work}

This survey helps to find about the level of awareness for the investors in stock trading technologies. The survey conveys that the investors are ready to invest in the market even though it has risk factors in it, but lack of knowledge of techniques to overcome the loss in the investments, they require proper guidance to invest.

They gain knowledge via media, online and in word of mouth but not aware of time of investment, not calculating the profit or the gain levels of the particular trade will reach, how to use the technics instantly when it is required for the situations happening. The study was conducted to understand the factors that influences Investors perception as well as to analyze the investor behavior with respect to various factors that influence an investment decision, level of awareness for each type of trading compared to the risk level.

\section{References}

[1] Ananthula Rambabu, Swapnil Chaudhari, Tarun Sangishetty, Ramesh Naidu G., Binay Bhushan Chakrabarti, "Arbitrage Opportunities in Indian Derivatives Market", Indian Institute of Management Calcutta, Working Paper Series, WPS No. 791 February 2017 (15)

[2] Arup Kumar Sarkar, Tarak Nath Sahu, "AN ENQUIRY INTO THE BEHAVIOUR OF INDIVIDUAL INVESTORS IN STOCK MARKET", - International Journal of Research in Finance and Marketing (IJRFM), Vol. 7 Issue 2, February - 2017, pp. 28 44. (6)

[3] Banumathy, R Azhagaiah, "Investors' Awareness About Investment in Stock Market"- Pacific Business Review International Volume 8, Issue 11, May 2016. (7)

[4] Gopi.E. Joseph paulraj. V, "Public Investment Awareness Towards Stock Market", Shanlax International Journal of Management, Vol. 5, No.1, July 2017. (14)

[5] HKEx Retail Investor Survey 2015 Key Findings-(16)

[6] Jaya.M, Malarvizhi.K, “ Sensitivity of The Investor's Towards Stock Market Investment"- International Journal of Marketing \& Financial Management, Volume 5, Issue 1, Jan-2017, pp 37-43 (11)

[7] Kajal Gandhi, "Retail Investors Participation in Indian Stock Market- A Survey OF KOLKATA", Adarsh Journal Of management Research ( ISSN 0974 - 7028) - vol. : 9 issue 1 March 2016. (9)

[8] Makarand S. Wazal, Sudesh Kumar Sharma, "Participation of Retail Investors in Indian Equity Market “ IOSR Journal of Business and Management (IOSR-JBM), Volume 19, Issue 9. Ver. I. (September. 2017), PP 78-80. (1)

[9] Malathy. M., Saranya.J, “A Study on Factors Infuencing Investors's Perception towards Stock Market Decision" - International Management and Business Studies, IJMBS Vol. 7, ISSue 3, July Sept 2017, (2)

[10] Mamtha and K. Sakthi Srinivasan, “ Indian Derivative Market: Investors' Risk Perspective" - International Journal of Economic Research - Volume 14, Number 14, 2017. (8)

[11] Neha S Shukla, “Investors' Preference towards Investment Avenues with Special Reference to Salaried Personnel in North Gujarat Region" - IJSART - Volume 2 Issue 1 -JANUARY 2016 (13)

[12] Purohit, Harshesh, GUJARTA NATIONAL LAW UNIVERSITY, Attalika Avenue Knowledge Corridor, and Koba Gandhinager 2012. "Role of SEBI in Indian Securities Market." Paripex - Indian Journal Of Research 3 (3): 86-88. (

[13] Radhika M, “A comparative study on investors' perception towards mutual fund and equity" - International Journal of Research in Management, Science \& Technology, Vol. 5, No. 2, August 17. (3)
[14] Rashmi Mate, D.Y. Patil Vidyapeeth, "Financial Literacy about Stock Market among the Participants of Bombay Stock Exchange", International Journal of Emerging Research in Management \&Technology, Volume-6, Issue-7, July 2017. (12)

[15] Raju N.S.V.N, Anita Patra, “A Study on Investor's Attitude towards Investment in Equity Stocks with Reference to Visakhapatnam District (Andhra Pradesh)" - International Journal of Latest Technology in Engineering, Management \& Applied Science (IJLTEMAS) Volume V, Issue XI, November 2016. (4)

[16] Sangeeta Arora Kanika Marwaha, "Financial Literacy Level and Awareness Regarding Stock Market - An Empirical Study of Individual Stock Investors of Punjab, Management and Labour Studies, First Published January 26, 2014 , SAGE Journals, (10)

[17] Securities and Exchange Board of India, SEBI Investor Survey 2015. (17)

[18] Venkatesha. $\mathrm{R}$ and Hiriyappa., "Investors perception towards Derivative Market with special reference to shivamogga" - Acme Intellects International Journal of Research in Management, Social Sciences \& Technology, Vol- 19 No. 19 Jul 2017 (5) 